\title{
Investigating the 'Case' of the Agnus Dei in Sixteenth-Century Italian Homes
}

\author{
Irene Galandra Cooper
}

On 26 July 1582, Giulia Diamante signed a deposition against her Spanish husband Francisco da Cordoba in front of the Vicar of the Neapolitan Archbishop, who acted on behalf of the Roman Inquisition. ${ }^{1}$ Giulia started her statement by recounting episodes of her unhappy married life: Francisco, who was extremely poor, had only married her for her large dowry and had tried to kill her many times over the years. However, this was not what brought Giulia to the Inquisition tribunal. Rather, she was spurred to denounce her husband on account of a borsetta di fattocchierie, 'a pouch full of magical items', that Francisco had been carrying around his neck and under his shirt for about three months. Giulia knew what the pouch contained because the previous Friday, while Francisco was asleep, she had stolen it to look at its contents. Shocked by what she saw, Giulia took it to the Inquisitor's vicar who, without further ado, initiated the trial against Francisco. Witnesses were called to testify against him; their testimonies, which repeated the same story, signalled the object's inexplicable mysterious charge. As one witness stated:

[I saw] Giulia holding an agnus dei, that is, a little round black velvet pouch, and it was open and inside I saw a piece of wood as little as the tip of a finger, a small piece of magnet, some flesh that looked like a pulsing heart, a broken piece of iron, some peppercorns and some other tricks. ${ }^{2}$

Francisco, however, told another story. To the Inquisitor's routine question about whether he knew the reason that had brought him to trial, he answered: 'because of the breve that I used to carry' ${ }^{3}$ Scholars who have studied brevi

1 Archivio Storico Diocesano di Napoli (ASDN hereafter), "Fondo Sant'Ufficio", 47.542 1582: "Io vidi Giulia tenere in mano un agnus dei, cioè una borzetta de velluto negro tonda quanto un giro de mezza grandezza et era aperta et subito dentro ce viddi un pezzo de ligno piccolo quanto una punta de ditto, un pezzetto piccolo de calamita, un poco di carne che parea un core che pulsava, un ferro ritorto, alcune acine de pepe e altri imbrogli".

2 Ibid., fol. gr.

3 Ibid., fol. 12r.

(C) IRENE GALANDRA COOPER, 2019 | DOI:10.1163/9789004375871_011

This is an open access chapter distributed under the terms of the prevailing CC-BY-NC-ND License at the time of publication. 
have identified them as prayers that, written on a small piece of paper, were kept close to the body, at times within fabric containers, as wearable amulets. ${ }^{4}$ He explained that he had worn his breve since the day his mother had given it to him as protection against life-threatening situations. From further questioning we gather that Francisco had never opened the pouch to see its contents, and that he believed it contained 'the agnus dei made of blessed wax [...] and I used to carry it as a sign of my devotion.' ${ }^{5}$

Francisco's accusation and subsequent trial are tied to the existence of two very different objects, both identified as agnus dei: a sanctioned wearable wax sacramental and a pouch containing illicit and magical objects. His case provides a window onto the heightened anxiety surrounding these items of domestic devotion and the interplay between correct and actual usages in early modern Italy. Devotion took many forms in early modern Italy, and by combining archival and material evidence, this essay will explore the 'case' of the agnus dei as a means to shed light on the nuanced devotional experiences of early modern Italians when not in Church.

\section{The Sacramental of the Agnus Dei}

The agnus dei, or 'Lamb of God', belonged to a category of devotional objects that, from the thirteenth century, was known as 'sacramentals' (sacramentalia), as opposed to sacraments (sacramenta). ${ }^{6}$ Originally, the term 'sacramentals' was exclusively used to indicate prayers and gestures performed during the administration of one of the seven sacraments, both in church and elsewhere. During the early modern period, 'sacramentals' also came to identify, extra-liturgically, all the objects blessed by the power of the Church and subsequently carried home, such as candles, flowers, palm leaves as well as rosary beads. ${ }^{7}$ In a time when childbirth, pestilence, wars and natural calamities could upturn the devotee's world, 'sacramentals' functioned as sanctioned

4 Cardini F., "Il 'breve' (secoli XIV-XV): tipologia e funzione", La Ricerca Folklorica 5: La scrittura: funzioni e ideologie (1982) 63-73. See also Tycz K., "Material Prayers and Maternity in Early Modern Italy: Signed, Sealed, Delivered", in this volume.

5 ASDN, 'Fondo Sant'Ufficio', 47.542 1582, fol. 14r.

6 Walker Bynum C., Christian Materiality: An Essay on Religion in Late Medieval Europe (New York: 2011) 145 .

7 Quinn J.R., "Sacramentals", in New Catholic Encyclopaedia 12 (London - Munich: 2003) 479481,48 o. For a study on 'sacramental' practices in seventeenth-century southern Italy see Gentilcore D., From Bishop to Witch. The System of the Sacred in Early Modern Terra d'Otranto (Manchester - New York: 1992) 95. 
intermediaries with the divine, as pre-Christian, or non-Christian amulets had done for centuries. ${ }^{8}$ In search of protection, early modern men and women sought out the sacred, in all its multiple forms, as the most powerful means of ordering an otherwise unpredictable and potentially dangerous world. ${ }^{9}$

Agnus dei were first conceived as wax tokens made from the remains of the Paschal candle of the previous year, which was blessed liturgically during the Easter celebrations as a sign of the Resurrected Christ. ${ }^{10}$ Meaning 'Lamb of God', their Latin name agnus dei simultaneously reveals their connection with Christ in the New Testament and with his prefiguration in the Old Testament. In fact, in Exodus, Christ is represented by the sacrificed lamb whose blood painted on Jews' households spared them from the wrath of God. ${ }^{11}$ In the New Testament, Christ's fulfilment of the Old Testament's prefiguration is sealed by John the Baptist, when he addressed Christ with the words: 'Behold the Lamb of God, who takes away the sins of the world. ${ }^{12}$

The blessing of the agnus dei has ancient origins. ${ }^{13}$ Sources point to the fifth century and the papacy of Zosimus who, in 417, granted a Paschal candle to all Roman parish churches. Probably responding to the requests of their parishioners, parish priests then started to distribute the remains of the Paschal candle of the previous year to the masses, who were eager to own a piece of the wax that was the symbol of the resurrected Christ as the light of the world. ${ }^{14}$ Over the centuries, the pieces of wax were shaped as small wax lambs, but subsequently came to adopt the simpler form of oval cakes. These were impressed with the image of the Lamb of God as well as the words Agnus Dei Qui Tollit Peccata Mundi on the recto, 'Lamb of God who takes away the sins of the world', and were dated and stamped with the name of the Pope who blessed them on the verso. From the mid-sixteenth century, the Pope sometimes chose alternative devotional representations of his name and arms to decorate the verso of the wax cakes..$^{15}$ One of the rare surviving sixteenth-century wax examples is an agnus dei that Gregory the XIII blessed and gave to the Jesuits

8 Amulets have been used since ancient times. See Walker Bynum, Christian Materiality $21-22$.

9 Scribner R.W., Popular Culture and Popular Movements in Reformation Germany (London: 1987) 7 .

$10 \quad$ McBrien R. (ed.), The HarperCollins Encyclopedia of Catholicism (London: 1995) 961.

11 Exodus, 12: 1-28.

12 John, 1: 29.

13 Bertelli S., Il corpo del re. Sacralità del potere nell'Europa medievale e moderna (Ponte Alle Grazie: 1995) 121-122.

14 Bertelli, Il corpo del re 117-127.

15 Moroni Romano G., "Agnus Dei di cera benedetti", in Dizionario di erudizione storico-ecclesiastica da S. Pietro fino ai nostri giorni, 10 vols. (Venice: 1840) vol. 1, 83-132. 
he sent to the British Isles. More specifically, this sixteenth-century agnus dei might have belonged to Saint Edmund Campion, as it was found in the attic of his last residence during renovation works carried out in 1959 [Figs. 9.1 \& 9.2]. ${ }^{16}$

While the sources are unclear about who made the wax discs, the most reliable information available suggests that the 'pontifical apothecary' (the socalled Magistrum Cerae Palatii Apostolici) manufactured the wax discs. This remained the case until 1592, when Clement VIII entrusted their creation to the Cistercians in the Church of Santa Pudenziana in Rome. ${ }^{17}$

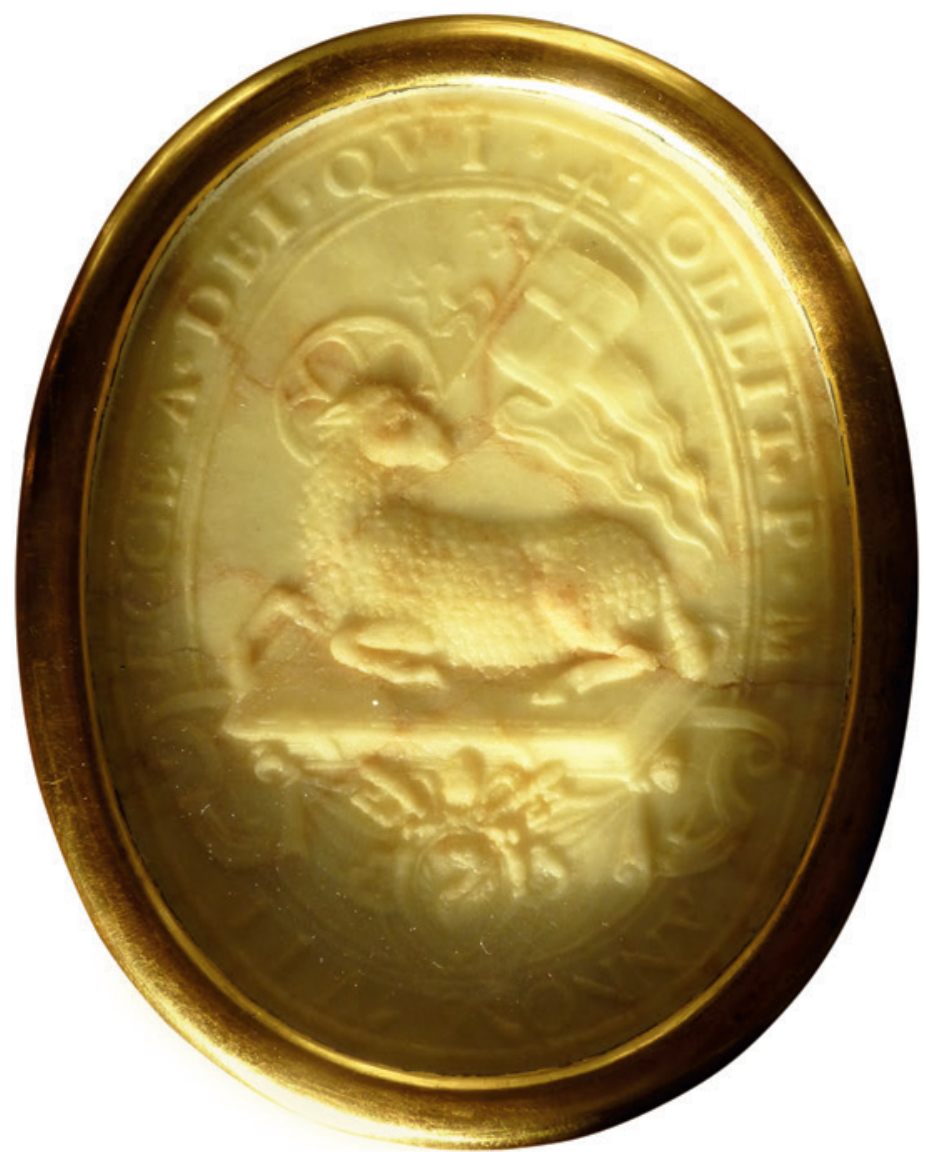

FIGURE 9.1 Agnus Dei, front, 16th century. Wax, Campion Hall

Collections, Oxford

(C) JESUIT INSTITUTE, LONDON

16 http://jesuitinstitute.org/Pages/Campion.htm [accessed on 29.01.2018].

17 Moroni Romano, “Agnus Dei” 129. 


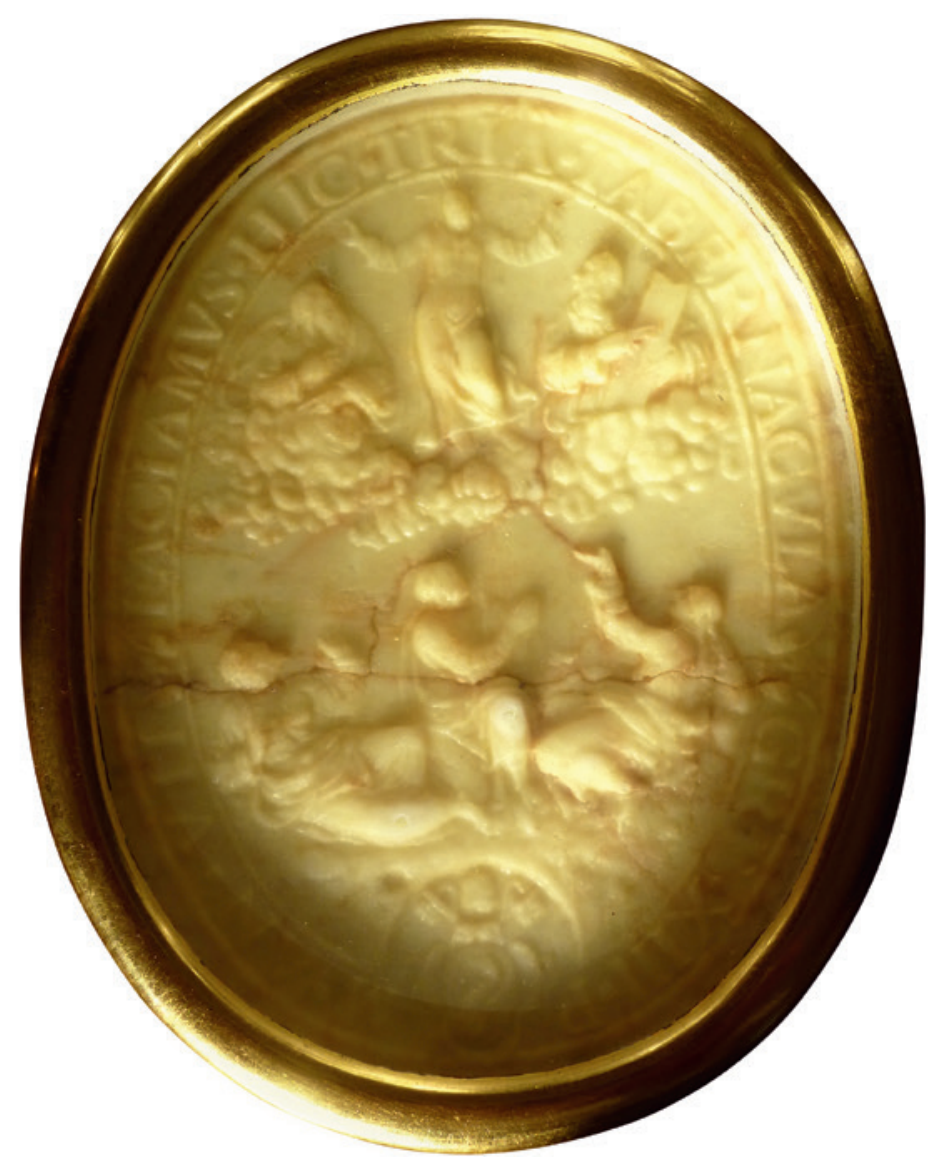

FIGURE 9.2 Agnus Dei, back, 16th century. Wax, Campion Hall Collections, Oxford

(C) JESUIT INSTITUTE, LONDON

Early modern and modern sources attest to a striking continuity - of gestures, colours and instruments - in the ritual of the blessing of the agnus dei. From the sixteenth century the rite took place on the first Saturday after Easter, known as in Albis, of a Pope's pontificate, and then every seventh year. ${ }^{18}$ In his diary, Johann Burchard, Master of Ceremonies to a succession of popes,

18 Bonardo Vincenzo, Discorso intorno all'origine, antichità et virtù degli Agnus Dei di cera benedetti (Rome, Vincenzo Accoliti: 1586). The most recent source that attests to such continuity is a video of Pope John XxiII blessing the agnus dei on his 78 th birthday in 


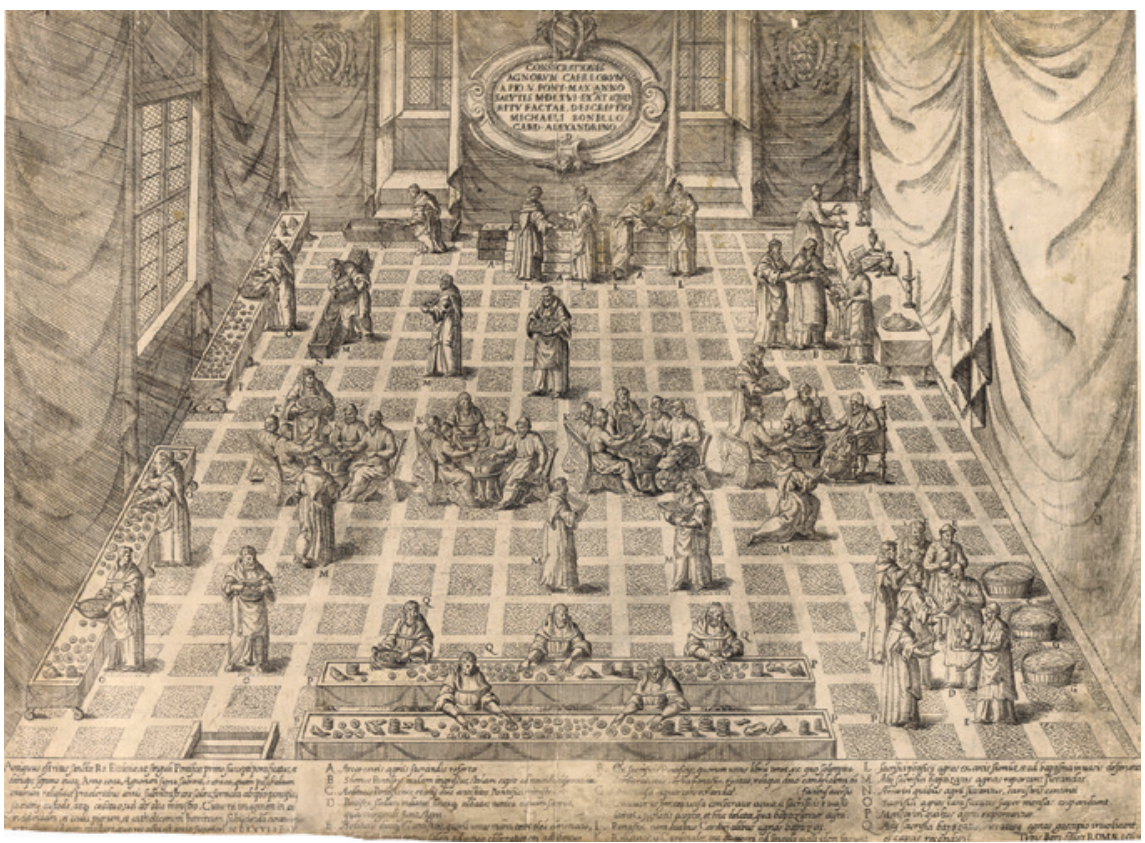

FIGURE 9.3 Bartolomeo Faleti, “Pope Pious V consecrating the 'wax lamb”, 1567. Etching on paper, $40 \times 54$, British Museum

(C) THE TRUSTEES OF THE BRITISH MUSEUM

gives a detailed description of Pope Innocent VIII blessing the agnus dei on 28 March $1486 .{ }^{19}$ Evoking the rites of baptism, the wax discs were dipped into silver basins filled with holy water, and then subsequently 'fished' with a silver ladle and handled over to the Cistercians who laid them on a nearby table to allow them to dry.

Strikingly, a century after his textual description, an almost exact visual counterpart to Burchard's words is found in a 1567 etching now at the British Museum [Fig. 9.3]. Printed in 1566 and dedicated to Pius v, the etching illustrates the Pope - clearly recognizable by his Dominican cap - as he moves around the room where the blessing took place. In the print, as in Burchard's description, there are silver basins and ladles, wax discs of a variety of sizes ready to be blessed and Cistercian monks busy handing wax cakes to the

1959: http://www.britishpathe.com/video/pope-blessing-angus-dei. The ritual of the blessing of the agnus dei ceased with the Second Vatican Council, 1962-1965.

19 The Diary of John Burchard of Strasburg, ed. A.H. Mathew (London: 1910) vol. 1: 1483-1492, 143-144. The 28th March 1486 was a Tuesday, and not a Saturday; because the Pope was unwell the ceremony had been moved to a different date. 
Pope or carefully laying them on a table to dry. ${ }^{20}$ In combination, the written text and its visual counterpart give us a clear idea of what the blessing involved.

However, both Burchard's diary and the print omit a fundamental detail that is recorded in other early modern sources. The agnus dei, tangible and portable reminders of the utmost immaterial Christ, were purposefully created to be given to the faithful and carried home: this important fact, which is also mentioned in the Ordines Romani, transformed the agnus dei into a household 'sacramental', sanctioned by Church authorities. ${ }^{21}$

\section{3}

\section{At Home}

In 1556 the Neapolitan Theatine Gian Pietro Carafa, then Pope Paul IV, commissioned the Dominican Vincenzo Bonardo to write the first treatise on the origins and the virtues of the agnus dei, entitled Discorso intorno all'origine, antichità et virtù degli Agnus Dei di cera, 'A Discourse On the Origins, History and Virtues of the Wax agnus dei. ${ }^{22}$ Following a historical investigation into the origins of the blessing of the agnus dei, Bonardo's essay introduces the important detail mentioned above: 'during the Saturday in Albis, after the mass and the communion, the agnus dei were distributed in church and given to the masses to take home.23 Within the home, as Bonardo specifies, the agnus dei could be kept at the head of the bed, a capo del letto - a detail of particular interest in the context of domestic devotion. ${ }^{24}$ The association with the bed is further illuminated by a sumptuary law from Ascoli Piceno in the Marche, which expressly limited the decoration of babies' cradles to a cross or an agnus dei, which was to be of a value not above ten florins and unpainted. ${ }^{25}$ Inquisition trials also attest to the practice of keeping the blessed agnus dei close to the bed. In one, an agnus dei is reported as being attached to a bed in the camera of a couple of Neapolitan newlyweds. More specifically, the agnus dei was hanging from the travacca, a Neapolitan term referring to the outer frame of a bed. Unfortunately, the location of the agnus dei was detected because of the irreverent acts of the husband, named as Giovanni Spinola, who threw it

\footnotetext{
20 The video mentioned in note 18 still shows the Cistercian monks.

21 As mentioned in Bertelli, Il corpo del re 117.

22 Bonardo, Discorso.

23 Ibid., 29.

24 Ibid., 29.

25 Archivio di Stato di Ascoli Piceno, Delle colationi dell'infante, et spese superflue delle culle et ornamenti de fanciulli. cap.o vi, fol. $8 \mathrm{v}$.
} 
angrily to the floor and smashed it to pieces - the reason behind his trial and imprisonment by the Inquisitor's vicar on 11 October $1595 .{ }^{26}$

Furthermore, Bonardo says that devotees were invited to bring the blessed wax cakes home and were also encouraged to burn them to release 'their perfume to help them in times of need' - their divine smell was produced by the added baptismal balsam. ${ }^{27}$ Evidently, many ignored this advice and treasured their agnus dei instead. In fact, according to Bonardo, the agnus dei would keep Satan, il Demonio, away from any household. ${ }^{28}$ Moreover, the blessed wax cake would assist women during childbirth and protect men and women from earthquakes, sea storms, wild winds and rains, hail, lighting and thunder, fires, inundations, plague and any diseases, as well as from sudden death. ${ }^{29}$

The aforementioned protective virtues were well known before the second half of the sixteenth century, as evidenced by the poem that Pope Urban VII wrote to accompany the agnus dei that he sent to the Byzantine emperor John Paleologus in 1362, together with the plea to unify the Eastern and the Western churches:

Balm and pure wax with the water of the chrism

Made the Agnus, that I give you as a great gift.

Born from a font, mystically sanctified,

It destroys ghosts and any malice,

Helps pregnant women in childbirth,

If carried with purity, it protects from the waves,

Shutters sin and suffering with Christ's blood.

It brings precious gifts, puts out fires,

Protects against sudden death, and from Satan's ruin.

If honoured, it wins trophies from enemies.

The smallest part alone is worth the whole.

Lamb of God, who takes away sins, have mercy on me. ${ }^{30}$

Given such understanding of their protective functions, it is not surprising that the laity employed the agnus dei in their daily lives by assigning them a variety of layered meanings that went beyond the univocal sacred power they represented. The most detailed and lively descriptions of the variety of ways

\footnotetext{
26 ASDN, 1106, 'Processo contro Giovanni Spinola', 1595, fol. 1r.

27 Bonardo, Discorso 29.

28 Bonardo Discorso 29.

29 Ibid., 55 .

30 The text of the letter is transcribed in Ceresole A., Notizie storico morali sopra gli Agnus Dei Benedetti (Rome: 1896) 36.
} 
in which people employed the sacramental of the agnus dei is found in a collection of miracles relating to Pope Pius v. Printed in 1672 , the Ristretto della vita, virtù e miracoli del Beato Pio $V$ draws on a variety of sources relating to the Pope's life and especially the transcripts from the trials for his beatification. The book is a eulogistic account of the Pope and the chapters are divided according to his virtues (such as temperance, fortitude, and purity). The last section, entitled Virtù mirabili degli Agnus Dei Benedetti dal Beato Pio Papa V, concerns the miracles that took place involving those agnus dei that bore the impression of the Pope's name on their verso and that were produced and distributed until his death in $1572 .{ }^{31}$ The miracles are categorised according to the virtues attributed to the agnus dei, making this seventeenth-century book the most comprehensive source for examples of the efficacy of the agnus dei.

Firstly, there are miracles relating to fire. Pius v's agnus dei are reported to have been thrown into burning houses in order to extinguish the flames and to have subsequently been retrieved unscathed; likewise, wounds vanished when the agnus dei was laid on badly burnt skin. ${ }^{32}$ These are followed by miracles relating to water. Flooding rivers and tumultuous seas are tamed by the throwing of the wax agnus dei into them, accompanied by the recitation of a 'Paternoster et una Ave Maria'. These same qualities of incombustibility and indestructibility were assigned to the Communion host, as well as to saints and their relics. ${ }^{33}$ The similarities between the blessed agnus dei and relics are furthered by another passage, which indicates the efficacy granted even to broken pieces of their wax. A felucca (boat) was heading from Rome towards Naples when a storm hit and threatened the lives of the passengers. A Franciscan friar who was on board asked all the passengers to kneel and recite one Paternoster and a Hail Mary while asking for the intercession of Pius v, and threw into the sea a particella (small piece) of the agnus dei. The grace was granted and the storm ceased, but only for a little while. Twice again the storm raged and twice again the friar broke two more pieces from his wax agnus dei and the wild winds and waves stopped. On the fourth, and last time, the skies blackened and the storm roared over the little boat, but the friar was left with his last piece of the agnus dei and did not want to be parted from it. The other passengers started crying and pleading with him to throw it into the waves as he had done three times before. The friar agreed, but not before having secured the last piece with a long string. Finally the storm stopped, the winds calmed

31 Ristretto della vita, virtù e miracoli del Beato Pio V (Rome, Angelo Tinassi: 1672) 237-251.

32 Such reports of incombustibility also appear in the history of Protestantism just after Luther's death. See Scribner, Popular Culture $323-353$.

Ibid., 328. 
down and the boat sailed all the way to Naples with the agnus dei trailing in the water. When the little felucca finally arrived in Naples, the friar retrieved the wax to find not the little piece, but a whole agnus dei, bearing the marks where he had broken it.

The treatise continues to list further miracles. The wax sacramental, whole or in pieces, was shown to protect the victims from bandits' attacks, or firearms and could be deployed during childbirth or any other instance when there was a great loss of blood. The examples reveal that the efficacy of the agnus dei resided in the whole cake as well as, like relics, small pieces of the blessed wax, a point emphasised by Urban vir's poem as well as Bonardo. ${ }^{34}$ This was perhaps to avoid devotees discarding the blessed wax cakes when broken. In the absence of validating documents, the division, indestructibility and miracles associated with the agnus dei were taken as proof of their authenticity.

Furthermore, assessing the sacramental's authenticity was necessary as the popularity of the agnus dei led to them being illicitly reproduced by stamping a wax form. The ease of making these fake agnus dei meant that they were manufactured all over Italy. ${ }^{35}$ In 1571, for instance, a silversmith named Sebastiano de Isopo was interrogated by the Neapolitan Inquisitor's vicar, after being accused of selling metal moulds for counterfeiting agnus dei. ${ }^{36}$ Both ecclesiastical authorities and the laity were thus faced with a concern about the authenticity of the agnus dei; if these objects were not genuine, it would undermine their efficacy once home.

\section{$4 \quad$ Wearing the Agnus Dei}

Church officials' belief in the powers of wax fragments of the agnus dei was probably a response to the impracticality of keeping the agnus dei intact. Although varying in size, surviving agnus dei are so thin that if held up to the light, they acquire a sort of translucency. The wax could be broken but could also easily collect dirt that would in turn corrupt their very important whiteness, a symbol of Christ's purity. The whiteness of the agnus dei was so important that in 1572, Pope Gregory XIII issued a Papal Bull dedicated to the

\footnotetext{
34 Bonardo, Discorso 55 .

35 Musacchio J.M., "Lambs, Coral, Teeth and the Intimate Intersection of Religion and Magic in Renaissance Italy", in Cornelison S.-J. - Montgomery S.B. (eds.), Images, Relics and Devotional Practices in Medieval and Renaissance Italy (Tempe: 2005) 139-156, 145; Lightbown R.W., Medieval European Jewellery with a Catalogue of the Collection in the Victoria and Albert Museum (London: 1992) 229.

$36 \quad$ ASDN, 157.1571.
} 
preservation of the wax's original colour, and prohibiting their painting and decorating: anyone, whether a 'man, or woman, lay or religious', who violated this rule, was subject to excommunication. ${ }^{37}$ Because of its physical fragility, Bonardo advises devotees to protect the agnus dei 'with fabric covers or containers made in bone or crystal. ${ }^{38}$ If broken, small pieces of the blessed wax could be encased in bronze, silver and crystal cases, and then attached to rosaries or worn as pendants from necklaces. ${ }^{39}$

Once enclosed in a container, the agnus dei was more likely to take on a life beyond the home as its devotional and apotropaic virtues were transferred to the individual that wore it close to his or her body. Official support for the encasing and wearing of the blessed wax generated the production, and trade, of a multitude of containers. John Cherry has investigated some of the French and English examples, but there is still little scholarship on the surviving early modern Italian ones. ${ }^{40}$

An examination of twenty-five sixteenth-century Neapolitan post-mortem inventories suggests that, after the rosary, the agnus dei was the second most popular devotional object. ${ }^{41}$ As the materials of the agnus dei are rarely mentioned, it is hard to distinguish between the whole Roman wax cakes and their containers. The array of materials used to make agnus dei containers was vast, and some were so luxurious that they transformed these items into stunning devotional pieces of jewellery. There are containers made of gold and crystal, or of gold, surrounded by pearls and garnets, or - in one case - of painted glass and black bone with a silver rosette. ${ }^{42}$ There are fabric containers, some

37 S.D.N.D. Gregorii PP. XIII Constitutione Agnus Dei benedicti minio inficiantur nec venales proponanur (Romae, Apud Haeredes Antonij Bladij Impressores Camerales: 1572).

38 Bonardo, Discorso 59 .

39 Ibid., 59 .

40 Cherry J. “Containers for Agnus Dei”, in Endwistle C. (ed.), Through a Glass Brightly: Studies in Byzantine and Medieval Art and Archaeology Presented to David Buckton (Oxford: 2003) 171-183.

41 Archivio di Stato di Napoli (hereafter ASN), 'Fondo Notai del Cinquecento'. The inventories I surveyed dated from 1521 to 1601 and belonged to non-élite Neapolitan citizens. The limited number of inventories surveyed is mainly due to the significant loss of materials in the archive during the Second World War. It is also partly a consequence of the lack of systematic cataloguing of sixteenth-century notarial records, which makes it difficult to navigate the archive. Although limited in number, the inventories of the less well-to-do Neapolitans have allowed me to work laterally from the trials and object-led analysis, and thus to expand the study of devotional objects found in the homes of ordinary people. ASN, 'Fondo Notai del Cinquecento': Notary Cav. Gio. Domenico, 88, vol. 1, Inventarium bonorum quondam Spetatoie Moaglio, 1575; notary Stinca F. Antonio, Inventarium bonorum quondam Joseph Cesarani, 1596 and Inventarium bonorum quondam Ferdinandi Funari, 1601 . 
embroidered, some in velvet of unspecified colours, and cheaper silver containers are also present. ${ }^{43}$ The only case in which the presence of the "wax agnus dei' is specifically recorded is amongst the possessions of a deceased Neapolitan citizen named Ferdinando Funari. ${ }^{44}$

Blessed in Rome, carried home for their devotional and protective virtues, suspended from people's necks as constant reminders of the sacred in their daily lives, agnus dei became one of the most popular portable devotional objects in early modern Italy. But were the agnus dei listed amongst people's devotional possessions all indicators of their owners' firm faith? If so, why was Francisco, with whom we opened this chapter, tried? The job of deciphering the nature of the laity's interaction with objects such as the agnus dei remains a difficult one. What is certain is that Francisco's trial was not an isolated case, and the agnus dei were not the only objects that were used in suspicious ways. During the Counter-Reformation, Church officials initiated militant and widespread action against a multitude of practices that involved a variety of sacramentals. ${ }^{45}$ Recent studies have shown that throughout the sixteenth century, the layered meanings ascribed by individuals to the sacred objects that they carried home became a point of unresolved tension between the ecclesiastical powers and the masses of devotees. ${ }^{46}$ Furthermore, there is scholarly agreement that the authorities' quest to eliminate any superstitious or magical behaviour was 'highly problematic, due to a pervasive uncertainty as to what constituted an offence in this matter'. ${ }^{4}$

43 ASN, 'Fondo Notai del Cinquecento', notary Stinca F. Antonio, Inventarium bonorum Joseph Cesarani, fol. $2 \mathrm{v}$ : 'di tela d'oro recamato de perle et granatelle' and fol. $5 \mathrm{r}$ : 'otto de velluto'.

44 ASN, 'Fondo Notai del Cinquecento', notary Stinca F. Antonio, 16oo, fol. 2 r.

45 Fantini M.P., "Saggio per un catalogo dai processi dell'inquisizione: orazioni, scongiuri, libri di segreti (Modena 1571-1608)", Annali dell'Istituto storico italo-germanico in Trento 25 (1999) 587-668; Fantini M.P., "La circolazione clandestina dell'orazione di Santa Marta: un episodio modenese", in Zarri G. (ed.), Donna, disciplina, creanza cristiana dal XV al XVII secolo. Studi e testi a stampa (Roma: 1996) 45-65; Burke P., The Historical Anthropology of Early Modern Italy: Essays on Perception and Communication (Cambridge: 1987); Gentilcore, From Bishop to Witch; Gentilcore D., Healers and Healing in Early Modern Italy (Manchester-New York: 1998); O'Neil M., "Sacerdote ovvero strione: Ecclesiastical and Superstitious Remedies in 16th Century Italy", in Kaplan S.L. (ed.), Understanding Popular Culture. Europe from the Middle Ages to the Nineteenth Century (Berlin-New YorkAmsterdam: 1984) 53-84.

46 Prosperi A., Tribunali della coscienza: inquisitori, confessori, missionari (Turin: 1996) 461463. On the efficacy on the campaign against superstitious behaviour see: De Boer W., 'Defining the Sinful: The Case of Superstition' in Id., The Conquest of the Soul. Confession, Discipline, and Public Order in Counter-Reformation Milan (Leiden - Boston: 2001) 295-322. De Boer, The Conquest of the Soul 296. 
The agnus dei could be encased and worn on the skin for constant protection. Uncertainty over what was contained inside generated great anxiety not only in church officials, but also amongst family members, neighbours and friends. Some pendants were easily identified as containers for sanctioned wax, but others were not. The attempt to unravel the accusation made against Francisco has led me to examine extant examples of Italian early modern agnus dei pendants.

The British Museum holds two unusually thick agnus dei pendants that would have contained a piece of the blessed wax. ${ }^{48}$ The first example is catalogued as 'pendant/cameo', and it is likely to have been serially produced by an averageskilled craftsman. The frame is in gilt-copper, the recto bears a Lamb of God imprinted onto a white material, possibly shell, and inscribed with the Latin Agnus Dei Qui Tollit Peccata Mundi [Fig. 9.4]. The colour of the front evocatively points to the white wax that could have been enclosed; and the verso has a niello decoration of a knotted cross [Fig. 9.5]. The frame on the verso of the pendant shows signs of usage, which suggest that this was probably the side that was worn close to the body, leaving the white shell exposed.

The second example is catalogued as a gilt-bronze 'medallion' [Fig. 9.6]. Both its recto and verso are decorated in niello, the former with the familiar 'Lamb of God', and the latter with a cross rising from a highly decorative inscription of the 'IHs'. In common with the first pendant, the back decoration and metal frame show signs of usage. The niello decoration of the agnus dei on the recto reveals similar rubbing marks, as if the owner were accustomed to touching it.

While the British Museum pendants are thick enough to have contained whole wax discs, the Victoria and Albert Museum holds two examples that point to an alternative way of wearing the blessed piece of wax. ${ }^{49}$ One pendant measures only one centimetre in diameter and is finely crafted [Fig. 9.7]. The recto is beautifully incised with a standing 'Lamb of God', while the verso bears the image of Christ's face impressed onto the so-called vernicle, or Veronica, which further encourages devotion to Christ. In fact, although an

48 British Museum, Inv. No. 1902,0527.26 and Inv. No. AF.2898.

49 Victoria and Albert Museum, Inv. No. M.94-1962. This speculation emerged during a fruitful discussion with Kirstin Kennedy from the Metalwork department of the museum, to whom I am very grateful. 

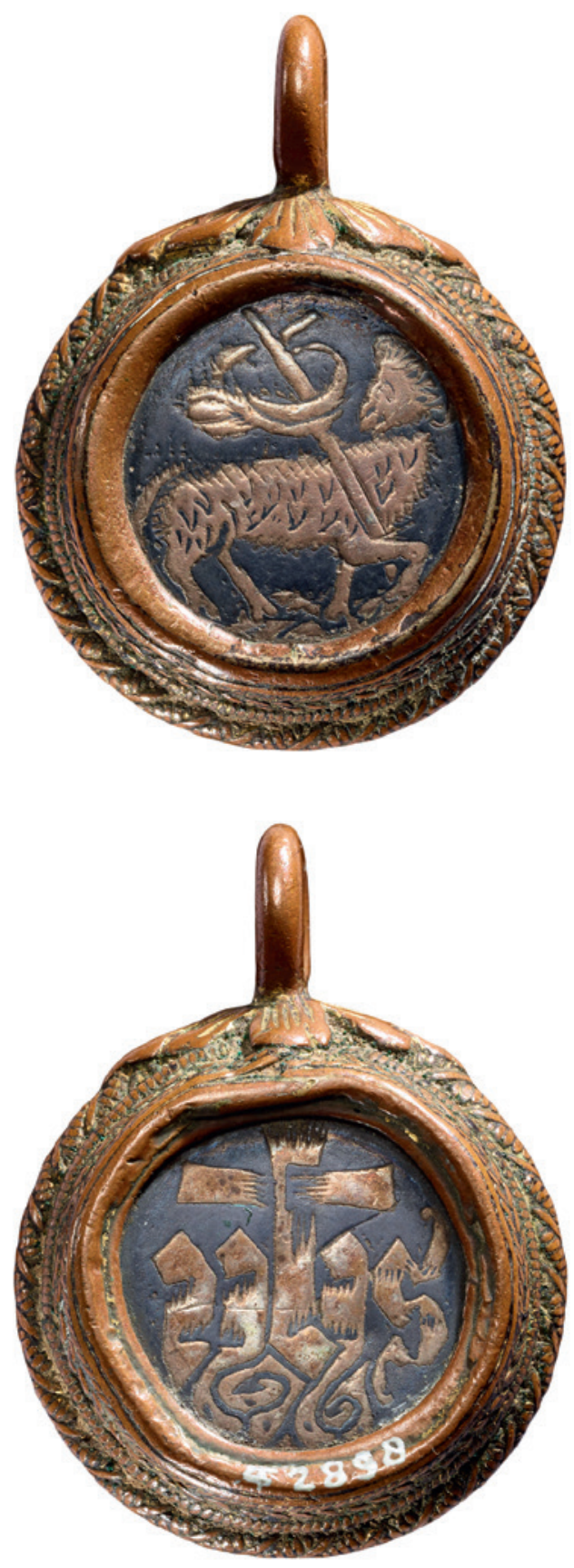

FIGURE 9.4

Pendant/Cameo, front, 16th century. Silver, shell, niello, gold, copper, $2.5 \mathrm{~cm}$ in diameter, British Museum

(C) THE TRUSTEES OF THE BRITISH MUSEUM

FIGURE 9.5

Pendant/Cameo, back, 16th century. Silver, shell, niello, gold, copper, $2.5 \mathrm{~cm}$ in diameter, British Museum (C) THE TRUSTEES OF THE BRITISH MUSEUM 


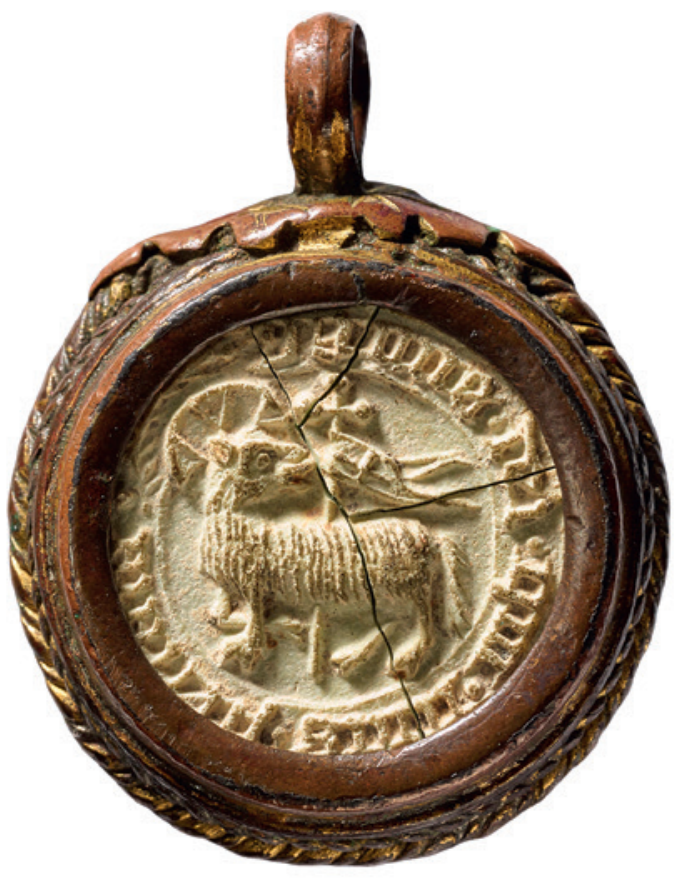

FIGURE 9.6

Medallion, 16 th century. Silver, niello, gold, $2.5 \mathrm{~cm}$ in diameter, British Museum

(C) THE TRUSTEES OF THE BRITISH MUSEUM

early medieval legend attributes the name Veronica to the woman who offered Christ a sweat cloth to wipe his face on his way up towards Mount Calvary, its name is etymologically tied to the Vera Ikon, or true image, that was forever impressed onto it. ${ }^{50}$ The frame is delicately worked with twisted silver-gilt strings. The second example is a little larger than the first one, and its decoration is less refined. ${ }^{51}$ The obverse shows a rougher version of the Lamb of God, the back features the 'IHs' script and the twisted frame is a little coarser. This second example is distinguished by a ring of pointed hooks that might have held a piece of wax right on top of the incised agnus dei.

A more elaborate example is preserved at the British Museum [Fig. 9.8].52 The central section can be opened to reveal the red velvet underneath, a later replacement of its original fabric, upon which the blessed wax once sat, and on the front the inscription Agni Dei Miserere Mei Qui Crimina Tollis, 'Lamb of God Who Takes Away the Sins Have Mercy on Me', whereas the back is engraved with the image of the Veronica [Fig. 9.9].

5o Hamburger J., The Visual and the Visionary: Art and Female Spirituality in Late Medieval Germany (New York: 1998) 317.

$5^{1}$ Victoria and Albert Museum, Inv. No. M.95-1962.

$5^{2}$ British Museum, Inv. No. AF.2699. 


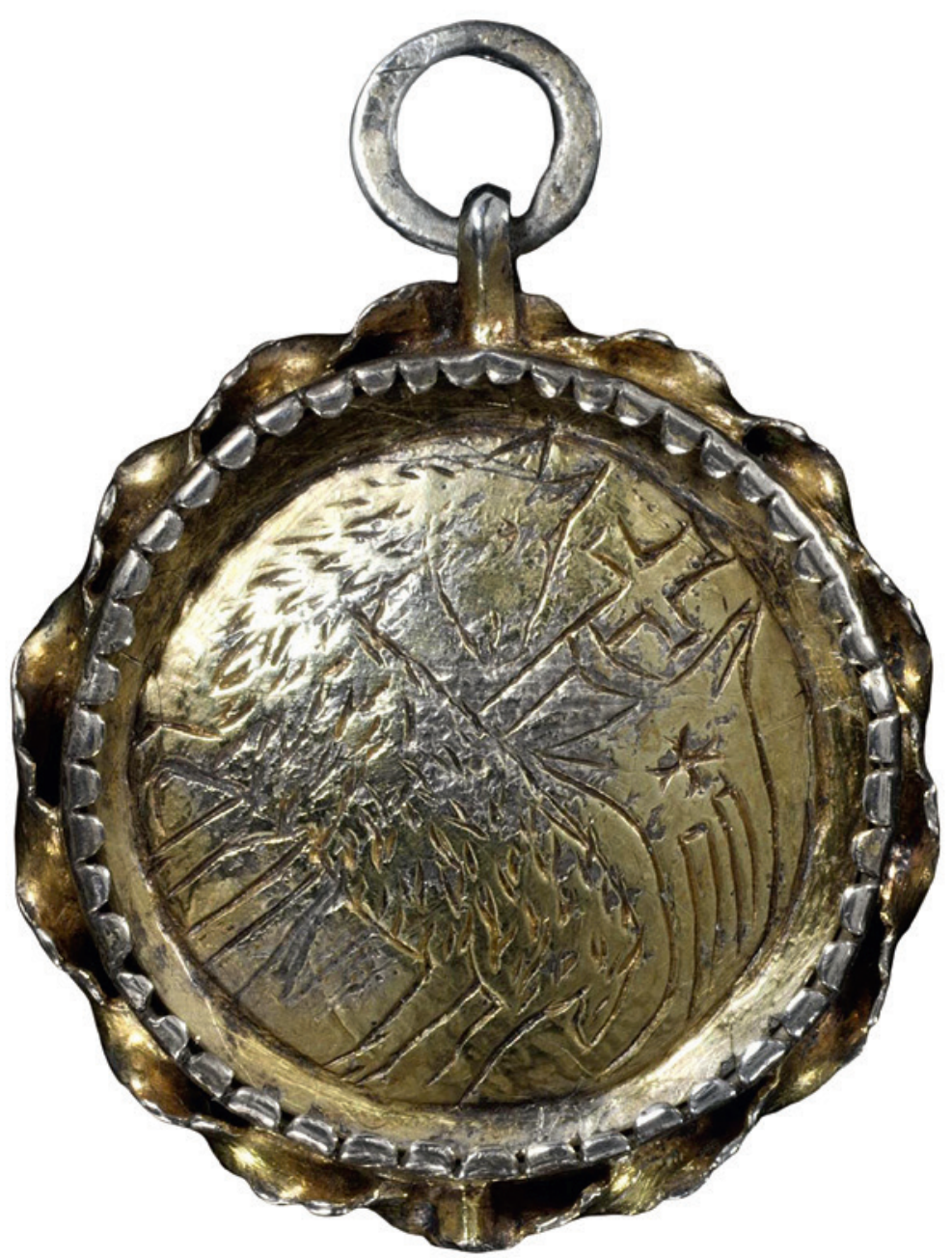

FIGURE 9.7 Pendant, 1400-1500. Silver, silver-gilt, $4 \times 2.8 \mathrm{~cm}$, Victoria and Albert Museum

(C) VICTORIA AND ALBERT MUSEUM, LONDON

The examples examined so far are made of gilt-copper, gilt-bronze and silvergilt. Thanks to the gilt-dipping process, these were visually enticing. Other materials - for example copper and bronze - were more affordable and allowed for the popularization of agnus dei [pendants or containers?] not only in Italy, but also throughout Europe. ${ }^{53}$ The physical characteristics of these museum objects allow us to speculate on these pendants originally being containers

53 Cherry, "Containers for Agnus Dei"; Lightbown, Medieval European Jewellery. 


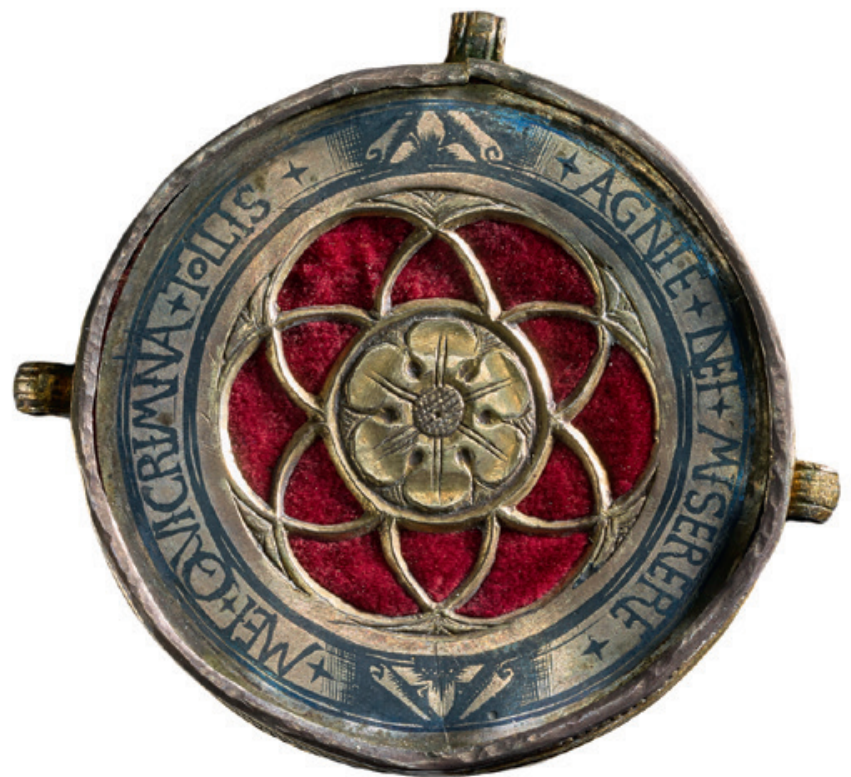

FIGURE 9.8 Medallion, front, 16th century. Silver, niello, gold, 2.5 diameter, British Museum

(C) THE TRUSTEES OF THE BRITISH MUSEUM

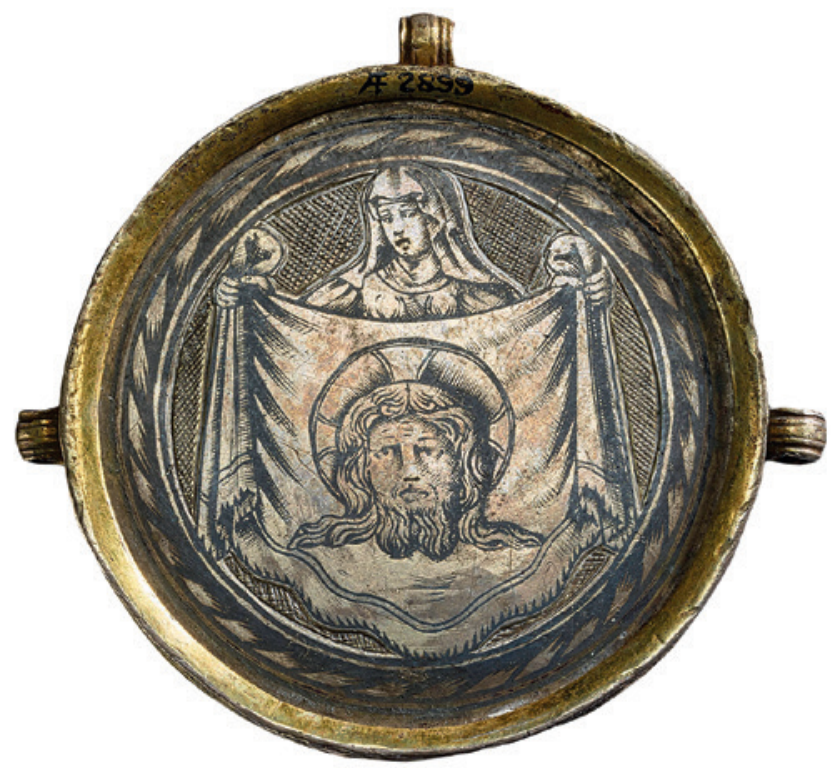

FIGURE 9.9 Medallion, back, 16th century. Silver, niello, gold, 2.5 diameter, British Museum

(C) THE TRUSTEES OF THE BRITISH MUSEUM 
for agnus dei. However, the survival of other very thin pendants, without devices such as hooks, raises the possibility that they might never have held the blessed wax, but were worn as reminders of Christ's divine presence. ${ }^{54}$

It is important to remember that the papal blessing and the distribution of the agnus dei only happened during the first Easter of the pontificate and every seventh year after that. It is likely that when the faithful arrived in Rome during the intervening six years when the Pope did not bless the wax agnus dei, small pendants with only the impression of the 'Lamb of God' were distributed as pilgrim tokens. A tiny pilgrim souvenir made from a humble lead alloy is held in the Museum of London. ${ }^{55}$ It was found on the Thames' shore, and yet its shape and its iconography point to Rome, and to the blessed wax discs. Of course, devotees could have owned agnus dei even if they never went to Rome: they could have been gifts from pilgrims; passed down from generation to generation; exchanged as dowry and childbirth gifts; or given as diplomatic gifts. ${ }^{56}$

Archival evidence attests to more unexpected ways in which agnus dei were distributed throughout Italy, and possibly beyond. For example, on 12 October 1595 the Venetian Inquisitor tried a certain Arduino da Vicenza, who was accused of falsely wearing a hermit's attire. ${ }^{57}$ Arduino was in fact a pilgrim, travelling from Naples with a letter of permission for his holy journey written on 24 March 1591 by the Archbishop of Naples, which included his destinations: the Holy House in Loreto, St Francis of Susa, the Blessed Mary Magdalene in Marseille and 'many other holy places' that he wanted to visit 'on account of his devotion'. ${ }^{8}$ Amongst Arduino's belongings, confiscated by the ecclesiastical officials, there was a box full of rosaries and agnus dei, that he had collected in Rome and was planning to give to monasteries and convents in exchange for alms. ${ }^{59}$

\footnotetext{
54 See, for instance: British Museum: AF.2898; Kunstgewerbemuseum, Berlin: F.1277g.

55 Museum of London, Inv. No. 2001.87.

56 de Olarra Garmendia J. - de Larramendi M.L., "Correspondencia entre la nunciatura en España y la Santa Sede durante el Reinado de Felipe III (1598-1621), II, Años 1602-1605”, Anthologia Annua 9 (1961) 495-816, 579 \& 584. I wish to thank Elisa Novi Chavarria for alerting me to this publication. ASv, 'Fondo Sant'Ufficio. Savi all'eresia', Busta 68, fasc. 4. I wish to thank Katherine Tycz for this information.

$5^{8}$ Ibid., fols. $1 v$ and 2 r.

59 Ibid., fols. 1 r and 3 r.
} 
Although not all the pendants examined in this essay could have contained wax, their decoration with the 'Lamb of God' may have given them the status of orthodox devotional objects. The problems started to arise when similar pendants to these were produced but without the image of the 'Lamb of God', instead bearing what Jacqueline Musacchio has defined as 'secular' representations..$^{60}$ Examining the image of a couple in profile on the recto of a pendant held at the British Museum, Musacchio defines the object as a marriage token. However the back of the pendant shows the 'IHS', and the same pairing of a marriage portrait with a devotional inscription is present on other sixteenth-century pendants. ${ }^{61}$ The shape, thickness and style of the pendants may have been so familiar to both the giver and the recipient that the explicit decoration of the 'Lamb of God' was not necessary. These pendants were not entirely secular, but were probably exchanged as wedding gifts invested with devotional and protective virtues.

The surviving pendants examined here suggest the tensions and negotiations that existed between the rituals of the Church and the everyday religion lived by ordinary men and women. More specifically, the agnus dei pendants signalled an open dialogue with Rome, the Pope, and ultimately the body of Christ that it was supposed to represent.

\section{$7 \quad$ Rising Anxiety}

Harder to reconcile with this argument are those pendants that bore neither images, nor inscriptions. Many sixteenth-century portraits of women show the sitters wearing what look like strings, small cords or chains tucked inside their clothes. We do not know what hung from such strings. Perhaps this very uncertainty about concealed objects contributed to the anxieties evident in Francisco's trial. There is no mention of any inscriptions on the black velvet pouch, which he wore under his shirt, and therefore no evidence to link it to the official Church. Perhaps this is the reason why Francisco's wife became suspicious of that velvet pouch. Strikingly, Francisco himself did not feel the need to question its devotional content as his mother had given it to him so that he could be protected against any dangers, thus signalling that a familial connection might have been even stronger than a sanctioned Church seal.

$60 \quad$ Musacchio, "Lambs, Coral" 149.

61 Metropolitan Museum of Art, New York, Inv. No. 17.190.965; Museum of Fine Arts, Boston, 69.74. 
Giulia Diamante's denunciation of her husband Francisco occurred just a few years before the publication of Bonardo's treatise. The ambiguity evident in the words of the accused and the accusers, that is, the description of the object as an agnus dei or a breve, is also present in Church sources. The most telling example is found in the biography of Suor Maria Villani (1584-1670), the founder of the Neapolitan convent of the 'Divino Amore', first published in $1676 .{ }^{62}$ The religiosity of Suor Maria was marked by an emotional relationship with Christ and the Virgin, characterised by ecstasy and visions which in turn inspired her apostolic mission towards her convent sisters, the secular clergy and her lay devotees. During the time of her illness, Maria's days were filled with visions during which she was surrounded by her Guardian Angel who on one occasion helped her to make 'brevetti o agnus dei. ${ }^{63}$ Suor Maria describes her brevetti, or agnus dei, as pouches that contained some relics of Saints, pieces of blessed wax, and pieces of paper upon which she wrote the beginning of the Gospel of St John, Verbum carofactumest, and all the different names of God. ${ }^{64}$ Suor Maria encased these treasures, at first with silk and golden thread but, worried that the nuns would keep them for their beauty rather than their content, she subsequently wrapped them in carta vergine, or virgin parchment, that she decorated with beautiful coloured flowers. ${ }^{65}$ Suor Maria's so-called agnus dei were then distributed to her convent sisters, the clergy and ordinary people who came to her because of her famous visions, who no doubt prized them for their protective and devotional qualities.

The ambiguity that characterised the 'sacramental' of the agnus dei, as well as of other objects such as the rosary as well as relics, provoked rising anxiety among Church officials. ${ }^{66}$ After Trent, ecclesiastical authorities tried to instruct the faithful on how to distinguish between orthodox and unorthodox devotional practices, by attempting to discipline the laity's relationship with sacramentals. ${ }^{67}$ However, as Adriano Prosperi has argued, the Tridentine Church failed in its attempt to control lay interactions with the sacred through

62 Vita della serva di Dio Suor Maria Viallani dell'ordine de' Predicatori (Milan, Federico Agnelli: 1676).

63 Vita della serva di Dio 315.

64 John, 1:1; Vita della serva di Dio 315.

65 Vita della serva di Dio 317. For carta vergine, see Skemer D.C., Binding Words: Textual Amulets in the Middle Ages, (University Park, PA: 2006) 131, he defines it as the 'parchment made from the tough membrane of an aborted fetus. [...] The purity of the parchment, uncontaminated by the outside world, could make a powerful amulet'.

66 For more examples of ambiguous behaviour towards sacramentals see: Galandra Cooper I., The Materiality of Domestic Devotion in Sixteenth-Century Naples, Ph.D. dissertation (University of Cambridge: 2016).

67 Prosperi, Tribunali 460. 
the means of devotional objects. ${ }^{68}$ The laity embraced and depended upon a kind of magical spirituality that they fit within their religious beliefs but that the authorities in Rome set against orthodox religion. This was true across Europe but perhaps especially so in southern Italy, where any form of uncontrolled recourse to sacred powers was seen with great suspicion. ${ }^{69}$

A similar dichotomy between 'official' and 'popular' that characterised the early modern Church has often structured the study of sixteenth-century devotional practices. In her research on early modern French religiosity, Virginia Reinburg has criticised the assumption that what was 'official' was indeed 'religious' whereas 'popular' is taken to mean 'superstitious or magical. ${ }^{70}$ Reinburg also points to the fact that 'the magic/religion framework prevents us from understanding pre-modern Christianity and early modern Catholicism, where earthly and spiritual freely mixed, and God's grace was understood [by the laity] to flow by means of words, rites and material objects.' ${ }^{71}$ It is likely that Francisco's attitude towards his agnus dei fitted within this more nuanced devotional experience.

The agnus dei, together with other devotional objects such as the rosary, was identified as a sort of 'badge of Catholicism' and condemned for its superstitious qualities by the followers of the new Protestant tradition. In 1579, agnus dei were depicted in Bernard Garter's A newe yeare's gifte dedicated to the popes holinesse. The print at the back of the book entitled 'Certaine of the Popes Merchandize lately sent over into Englande' showed the Catholic objects most representative of such superstitious faith, amongst which is illustrated an agnus dei pendant. ${ }^{72}$

The importance of the agnus dei to Catholic identity and its simultaneous denunciation by Protestants is attested to by another Inquisition trial from Naples. ${ }^{73}$ In 1594, Giovanni Osso was accused of 'being a Lutheran', and during his interrogation he recounted how he had once followed another Lutheran named Annibale Virgilio from Rome to Germany, during which time Annibale had asked Giovanni to fill his boots with blessed agnus dei and rosaries, so that when they arrived in Germany, they could hang them in their dog-house. ${ }^{74}$

\footnotetext{
68 Ibid., 461.

69 Gentilcore, From Bishop to Witch.

70 Reinburg V., The French Book of Hours. Making an Archive of Prayer, c.1400-160o (Cambridge: 2014) 161 .

71 Reinburg, The French Book of Hours 160.

72 Garter B., A newe yeare's gifte dedicated to the popes holinesse (London, Henry Bynneman: 1579) 57 .

73 ASDN, 78.937.1594, fol. 1v.

74 ASDN, 78.937.1594, fol. 1v.
} 
While previous studies have shed light on the popularity of the agnus dei amongst people's possessions in early modern Italy, little attention has been given to their materiality in relation to everyday devotional practices.

Although made to be handed to the faithful in Rome and to be brought back into their homes, this essay has illustrated how small pieces of the blessed wax were often encased in pendants and worn outside the home. True enough, written evidence, from post-mortem inventories to early modern treatises and private correspondence, tends to situate agnus dei within the domestic sphere. Nevertheless, research conducted in the Neapolitan archives draws attention to the conscious decision on the part of some devotees to be separated from their so vital 'sacramental'. The archive of the sanctuary of Madonna dell'Arco just outside Naples holds an anonymous manuscript book of all the objects and textiles brought to the miraculous image of the Virgin and Child between 1592 and $1594 \cdot{ }^{75}$ The entries fill 195 folios and reveal an ample array of objects taken to the shrine by people from all levels of society. Among them are wax agnus dei, and also containers, often of humble metals. Kept at home, worn close to the body or even taken back to the Church as an ex-voto, the 'case' of the agnus dei can take the study of early modern lived religion beyond the opposition between popular and high religion, or sanctioned and magical beliefs, to show more nuanced possibilities of what it meant to be Catholic in early modern Italy.

Early modern people acquired these objects for their devotional and protective qualities, and the sacred could thus be brought into the secular world to aid them in keeping order in their daily lives and the natural world. ${ }^{76}$ Simultaneously, during moments of extraordinary and ordinary need, for example a natural calamity or an illness, the same objects were used as 'trading tokens' with the Deity: agnus dei vowed in exchange for the granting of a grace.

In the hands of the faithful, the small wax cake with the imprint of the agnus dei was more than just a devotional symbol. The imprint of the Pope's seal embodied the official seal of the Church, and the presence of the agnus dei was a reference to Christ. Furthermore, the fleshy materiality of the wax, its density, grain, colour and brilliance, may have sparked a strong analogy with

75 Libro nel quale si notano giornalmente tutte li mobili come sono voti d'argento, o oro, calici, lampe d'argento, panni d'altare, tovaglie et ogni altra sorte di paramenti di lino, lana et seta, che si donano alla Madonna devotissima dell'Arco di Santo Nastase dal sottoscritto di avanti, et cosi anco anella o altre cose d'oro o d'argento eccetera, (1592-1594). 
the consecrated host that was supposed to be the sole bearer of the flesh and blood of Christ. Once in the homes of the faithful, the divine presence was marked even further by burning parts of the blessed wax.

The spiritual virtue given by the Pope's blessing, the tactile wax, the perfumed balsam, the reference to the consecrated bread and the Latin antiphon recited during mass, gave the agnus dei added sensorial virtues that enhanced devotees' experiences. Moreover, Christ's wax seal in the form of the agnus dei, produced with the intent of helping to form pious domestic environments, was entirely left in the hands of the laity. The transcendental and the mysterious thus came within close reach of the familiar.

\section{Selected Bibliography}

\section{Pre-18oo books}

Bonardo Vincenzo, Discorso intorno all'origine, antichità et virtù degli Agnus Dei di cera benedetti (Rome, Vincenzo Accoliti: 1586).

Ristretto della vita, virtù e miracoli del Beato Pio V (Rome, Angelo Tinassi: 1672).

\section{Post-18oo books}

Bertelli S., Il corpo del re. Sacralità del potere nell'Europa medievale e moderna (Ponte Alle Grazie: 1995).

Cherry J., "Containers for Agnus Dei", in Endwistle C. (eds.) Through a Glass Brightly: Studies in Byzantine and Medieval art and archaeology presented to David Buckton (Oxford: 2003) 171-183.

Gentilcore D., From Bishop to Witch. The System of the Sacred in Early Modern Terra d'Otranto (Manchester - New York: 1992).

Hamburger J., The Visual and the Visionary: Art and Female Spirituality in Late Medieval Germany (New York: Zone Books, 1998).

Lightbown R.W., Medieval European Jewellery with a Catalogue of the Collection in the Victoria and Albert Museum (London: 1992).

McBrien, R. (ed.), The HarperCollins Encyclopedia of Catholicism (London:1995).

Moroni Romano G., "Agnus Dei di cera benedetti," in Dizionario di erudizione storicoecclesiastica da S. Pietro fino ai nostri giorni, vol. 1 (Venice: 1840) 83-132.

Musacchio J.M., "Lambs, Coral, Teeth and the Intimate Intersection of Religion and Magic in Renaissance Italy", in Cornelison S.-J. - Montgomery S.B. (eds.), Images, Relics and Devotional Practices in Medieval and Renaissance Italy (Tempe: 2005) 139-156.

Prosperi A., Tribunali della coscienza: inquisitori, confessori, missionari (Turin: 1996). 
Quinn J.R., "Sacramentals", in New Catholic Encyclopaedia, 12 (London - Munich: 2003), 479-481.

Scribner R.W., Popular Culture and Popular Movements in Reformation Germany (London: 1987).

The Diary of John Burchard of Strasburg, ed. A.H. Mathew (London: 1910) vol. 1: 1483-1492.

Walker Bynum C., Christian Materiality: an Essay on Religion in Late Medieval Europe (New York: 2011). 